\title{
A scientific note on amoeboid movement of honey bee semen
}

\author{
Adam ToFILSKI \\ Department of Pomology and Apiculture, Agricultural University, 29 Listopada 54, PL 31-425, Krakow, Poland
}

Received 22 October 2013 - Revised 18 December 2013 - Accepted 3 January 2014

\section{honey bee / Apis mellifera / spermatozoa / amoeboid movement / sperm cooperation}

Honey bee (Apis mellifera) semen is a tan, viscous liquid containing tightly packed and slowly moving spermatozoa (Stort \& Goncalves 1986). Immediately after transfer of spermatozoa to the queen's spermatheca, they move faster, but after $1 \mathrm{~h}$, the movement stops (Kerr et al. 1962) and later during storage the spermatozoa remain immotile (Lensky \& Schindler 1967). The immotility is reversible as long as the spermatozoa are alive (Verma 1978). In nature, honey bee semen is diluted with spermathecal fluid but the spermatozoa survive also in many human made diluents (Moritz 1984; Taylor et al. 2009).

Here, I report that diluted honey bee semen behaves in an unusual way; it produces pseudopodia and is able to move. The movement differs from the amoeboid movement of a single spermatozoon (Nelson \& Ward 1981) and involves the coordinated behaviour of a group of spermatozoa.

Honey bee drones were collected at hive entrances and were stored in a cage attended by workers. To initiate ejaculation, the abdomen of a drone was pressed with fingers, a standard method (Laidlaw \& Page 1997). The semen was collected with a syringe designed for instrumental insemination of honey bee queens. The semen was evacuated from the syringe onto a microscopic slide. From there, it was collected

Electronic supplementary material The online version of this article (doi:10.1007/s13592-014-0269-2) contains supplementary material, which is available to authorized users.

Corresponding author: A. Tofilski, rotofils@cyf-kr.edu.pl

Manuscript editor: Klaus Hartfelder passively into a MEDLAB glass capillary (inside diameter $0.7 \mathrm{~mm}$, outside diameter $1.3 \mathrm{~mm}$ and length $50 \mathrm{~mm}$ ). The semen inside the capillary was diluted 1:1 (v/v) with spermathecal fluid obtained from a young uninseminated honey bee queen. Its spermatheca was dissected from the queen immediately before the experiment and crushed on a microscope slide. The spermathecal fluid was collected using the insemination syringe, and a droplet of it was evacuated onto another clean microscopic slide. When the capillary with semen was brought into contact with the droplet, it was drawn into the capillary and diffused through the semen. The capillary was positioned horizontally, and it was photographed every hour with a Nikon D70 digital camera to determine the speed of semen movement. The experiment was repeated 10 times using the semen of different drones.

The behaviour of diluted semen on a microscopic slide was observed with a Nikon Eclipse E600 microscope. Semen movement was recorded with a JVC colour video camera (resolution $720 \times 576$ ) attached to the microscope. In some experiments, the droplet of diluted semen was surrounded by six small droplets of spermathecal fluid. There was a distance of about $0.2 \mathrm{~mm}$ between the droplet of semen and the droplets of spermathecal fluid. If a pseudopodium formed near a droplet of diluent, it was video recorded.

In all experiments, the capillaries or microscope slides with semen were kept in a transparent plastic container with a tissue wetted with distilled water. The wet tissue provided high humidity and prevented the semen from drying. In some experiments, the semen was diluted in Kiev buffer instead of spermathecal fluid. The Kiev buffer consisted of $0.3 \mathrm{~g} \mathrm{D}+$ glucose, $0.41 \mathrm{~g}$ 
potassium chloride, $0.21 \mathrm{~g}$ sodium bicarbonate and 2.43 g sodium citrate per $100 \mathrm{~mL}$ water (Paufler 1974; Collins \& Donoghue 1999).

In the capillary, undiluted honey bee semen behaved like any other highly viscous liquid - when it was drawn into the capillary, it remained at the end of it. The semen behaved differently when it was diluted 1:1 (v/v) with spermathecal fluid obtained from an uninseminated honey bee queen. The diluted semen did not stay at the end of the capillary: its whole volume travelled slowly along the capillary towards the opposite end. During the first hour, the semen travelled at $0.13 \pm 0.04 \mathrm{~mm} / \mathrm{min}$ (mean $\pm \mathrm{SD}$; $n=10$ ), slowing down with time (Figure 1).

Observations by light microscopy revealed pseudopodia inside the capillary at the front of the column of diluted semen (Figure 2a, Online Movie 1). Pseudopodia formed not only in the capillary experiment but also at the edge of a droplet of diluted semen on a microscope slide. On the slide, the droplet did not go in any specific direction but spread in all directions (Figure 2b, Online Movie 2). The pseudopodia were formed by a large number of spermatozoa tightly packed along each other (Figure 2a). In some circumstances, a group of spermatozoa aligned themselves along their lengths and synchronized the action of their flagella. A pseudopodium was formed when the force produced by the group of synchronized spermatozoa was strong enough to overcome the liquid's surface tension. The pseudopodium lengthened and widened over time as other spermatozoa joined it. Immediately after forming, the pseudopodium extended perpendicularly to the edge of the liquid but its later direction of extension varied. Some pseudopodia bifurcated or re-entered the droplet of semen (Figure 2b). Some pseudopodia were longer than the length of one spermatozoon, which is $250-270 \mu \mathrm{m}$. This suggests that the spermatozoa at the front of the pseudopodium were pushed by those behind them. Honey bee semen also showed amoeboid movement when diluted not with spermathecal fluid but with Kiev buffer.

To simulate filling of the spermatheca, I placed small droplets of diluent next to a droplet of diluted semen. If a pseudopodium extending from the diluted semen reached a droplet of diluent, a stream of spermatozoa entered the droplet (Figure 2c, Online Movie 3). The spermatozoa spread out inside the droplet and filled it completely.

The results presented here show that diluted honey bee semen can move by producing pseudopodia. The amoeboid movement of diluted semen can be triggered by the presence of carbohydrates in the diluent or by reduction of the semen's viscosity. The reduction of movement speed with time probably is related to depletion of the sugars present in the semen (Blum et al. 1962).

During honey bee mating, semen is transferred from the drone's seminal vesicles to the queen's lateral oviducts (Koeniger et al. 2011). From there, it migrates to the spermatheca through the spermathecal duct, which is less than $25 \mu \mathrm{m}$ in diameter (Ruttner 1956). The semen does not inflate the spermatheca but replaces the fluid present there (Dade 1994). Several mechanisms of the transfer have been suggested including semen pump (Bresslau 1905), contraction of oviducts (Ruttner \& Koeniger 1971) and active spermatozoa movement (Collins 2000). Amoeboid movement of semen could be critical to the transfer of sperm from oviducts to the spermatheca because it would allow the semen to spread into any air pocket formed at the entrance to the spermathecal duct. It is sometimes suggested that the transfer of sperm from
Figure 1. Honey bee semen diluted with spermathecal fluid moves inside capillary. The mean speed $( \pm \mathrm{SD})$ of that movement decreases with time.

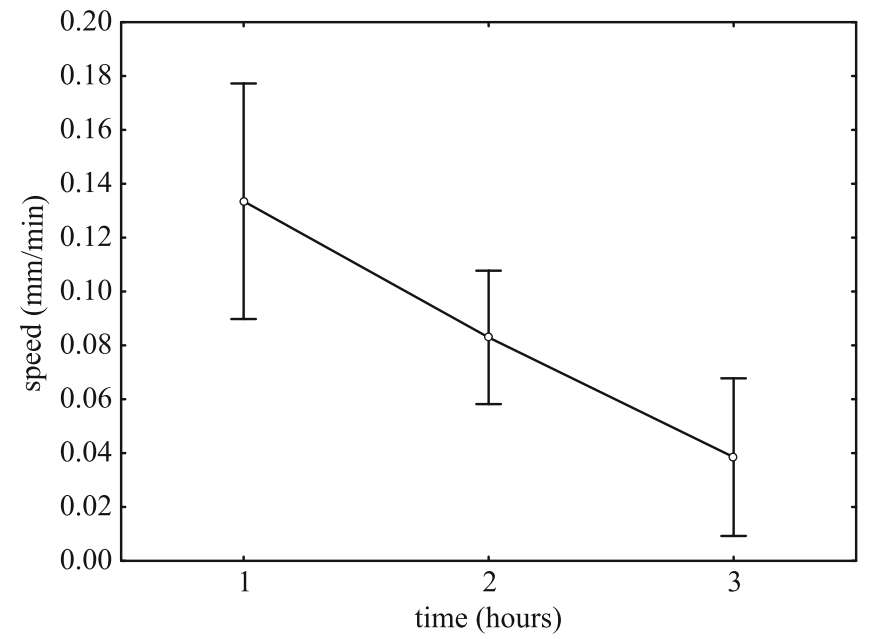


Figure 2. Honey bee semen diluted with spermathecal fluid forms pseudopodia (1) and is able to move. The pseudopodia consist of a large number of spermatozoa aligned tightly along each other (a) and moving in synchrony (Online Movie 1). Pseudopodia extend from a droplet of semen in various directions (b, Online Movie 2); some reenter the semen droplet from which they emerged (2), others bifurcate (3). When a pseudopodium encounters a droplet of spermathecal fluid (4), the spermatozoa enter it (c) and form a visible layer (5) which spreads inside the droplet and finally fills it completely (Online Movie 3). This is similar to filling of the spermatheca by spermatozoa after mating. Scale bars: a $0.1 \mathrm{~mm}$, b and c $0.5 \mathrm{~mm}$.

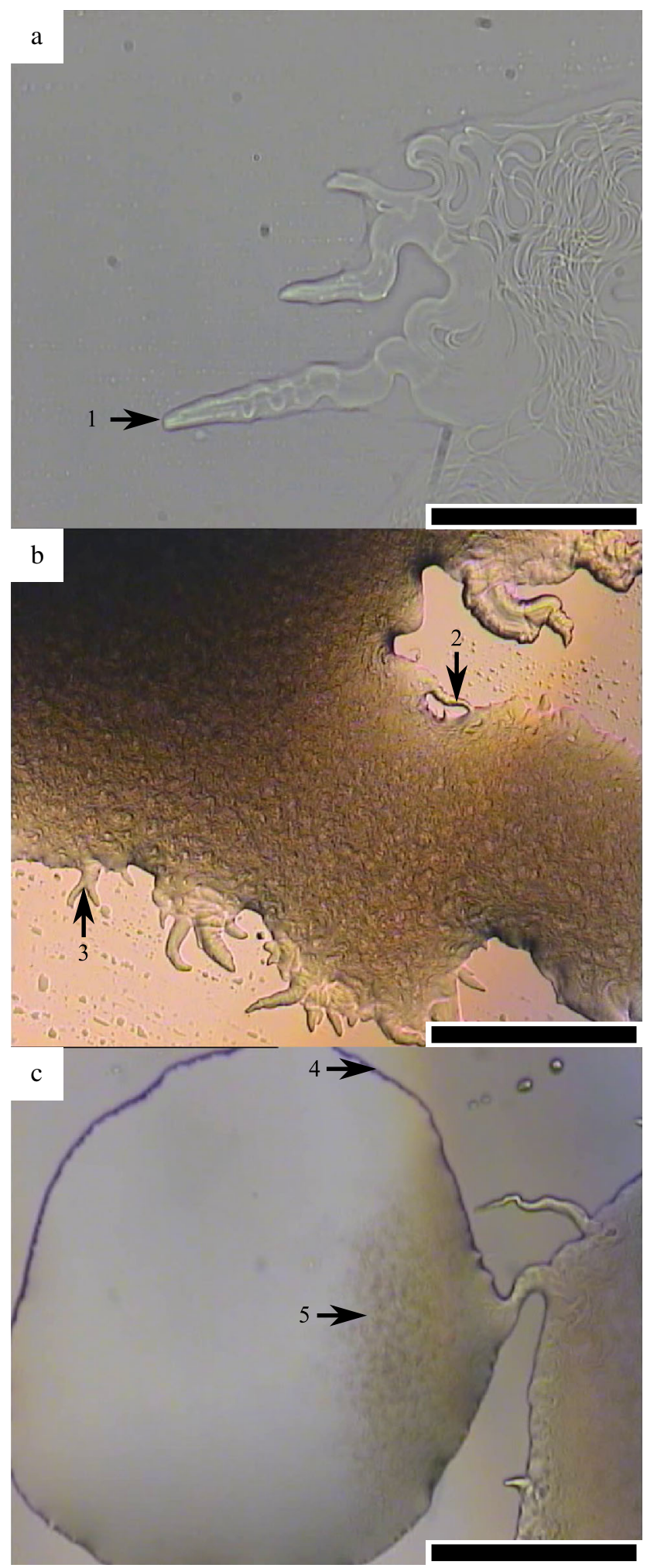


oviducts to the spermatheca is partly due to suction produced by the spermathecal pump (Koeniger et al. 2011). My experiment shows that such suction is not required. The spermatozoa can traverse any narrow tube using only the propulsive force of their flagella.

Honey bee queen oviducts contain the semen of many drones, only a small fraction of which can fit into the spermatheca. Usually, the queen's sexual partners are unrelated and the spermatozoa of different drones compete to enter the spermatheca (Woyciechowski \& Król 1996; Shafir et al. 2009; Tofilski et al. 2012). The spermatozoa of a single drone have the same genes (except for mutations) and should cooperate (Foster \& Pizzari 2010). The spermatozoa that make up a pseudopodium cooperate by synchronizing their flagella and thereby increase their chance of getting into the spermatheca. The spermatozoa at the tip of the pseudopodium benefit from the action of spermatozoa at the base of the pseudopodium. This amoeboid movement of honey bee semen can be considered a form of sperm cooperation, newly found, which allows faster transfer of spermatozoa from oviducts to the spermatheca.

\section{ACKNOWLEDGMENTS}

I thank Michael Jacobs and two anonymous reviewers for helpful comments on earlier versions of this paper. This work was funded by Ministry of Science and Higher Education grant No. N N311 292436.

\section{OPEN ACCESS}

This article is distributed under the terms of the Creative Commons Attribution License which permits any use, distribution, and reproduction in any medium, provided the original author(s) and the source are credited.

\section{Note scientifique sur le mouvement amiboïde du sperme d'abeille}

Eine wissenschaftliche Notiz über amöboide Bewegungen in Honigbienensperma

\section{REFERENCES}

Blum, M.S., Glowska, Z., Taber, S. (1962) Chemistry of the drone honey bee reproductive system. II. Carbohydrates in the reproductive organs and semen. Ann. Entomol. Soc. Am. 55, 135-139
Bresslau, E. (1905) Der Samenblasengang der Bienenkönigen. Zool. Anz. 29, 299-323

Collins, A.M. (2000) Relationship between semen quality and performance of instrumentally inseminated honey bee queens. Apidologie 31, 421-429

Collins, A.M., Donoghue, A.M. (1999) Viability assessment of honey bee, Apis mellifera sperm using dual fluorescent staining. Theriogenology 51, 1513-1523

Dade, H.A. (1994) Anatomy and dissection of the honeybee. International Bee Research Association, London, UK

Foster, K.R., Pizzari, T. (2010) Cooperation: The Secret Society of Sperm. Curr. Biol. 20, R314-R316

Kerr, W.E., Zucchi, R., Nakadaira, J.T., Butolo, J.E. (1962) Reproduction in the social bees (Hymenoptera: Apidae). J. N.Y. Entomol. Soc. 70, 173-176

Koeniger, G., Koeniger, N., Phiancharoen, M. (2011) Comparative reproductive biology of honeybees. In: Hepburn, H.R., Radloff, S.E. (eds.) Honeybees of Asia, pp. 159-206. Springer, Berlin

Laidlaw, H.H., Page, R.E. (1997) Queen rearing and bee breeding. Wicwas Press, Cheshire

Lensky, Y., Schindler, H. (1967) Motility and reversible inactivation of honeybee spermatozoa in vivo and in vitro. Annales de l'Abeille 10, 5-16

Moritz, R.F.A. (1984) The effect of different diluents on insemination success in the honeybee using mixed semen. J. Apic. Res. 23, 164-167

Nelson, G.A., Ward, S. (1981) Amoeboid motility and actin in Ascaris lumbricoides sperm. Exp. Cell Res. 131, 149-160

Paufler, S.K. (1974) Die künstliche Besamung beim Schwein. In: Paufler, S.K., Bader, H., Bonfert, A., Foote, R.H., Salomon, S., Vasterling, H.W. (eds.) Künstliche Besamung und Eitransplantation bei Tier und Mensch, pp. 81-98. Verlag Schaper, Hannover, Germany

Ruttner, F. (1956) Zur Frage der Spermaübertragung bei der Bienenkönigin. Insect. Soc. 3, 351-359

Ruttner, F., Koeniger, G. (1971) Die Fullung der Spermatheka der Bienenkonigin Active Wanderung oder passiver Transport der Spermatozoen? Z. vergl. Physiologie 72, 411-422

Shafir, S., Kabanoff, L., Duncan, M., Oldroyd, B.P. (2009) Honey bee (Apis mellifera) sperm competition in vitro- two are no less viable than one. Apidologie 40, 556-561

Stort, A.C., Goncalves, L.S. (1986) Storage of Germplasm. In: Rinderer, T.E. (ed.) Bee Genetics and breeding, pp. 345359. Academic, Orlando

Taylor, M.A., Guzman-Novoa, E., Morfin, N., Buhr, M.M. (2009) Improving viability of cryopreserved honey bee (Apis mellifera L.) sperm with selected diluents, cryoprotectants, and semen dilution ratios. Theriogenology 72, 149-159

Tofilski, A., Chuda-Mickiewicz, B., Czekonska, K., Chorbiński, P. (2012) Flow cytometry evidence about sperm competition in honey bee (Apis mellifera). Apidologie 43, 63-70

Verma, L.R. (1978) Biology of honeybee (Apis mellifera L.) spermatozoa. 1. Effect of different diluents on motility and survival. Apidologie 9, 167-174

Woyciechowski, M., Król, E. (1996) On intraoviductal sperm competition in the honeybee (Apis mellifera). Fol. Biol. 44, 1-2 